would, in a criminal case, hesitate to convict for perjury. Again, in the criminal case of Reg. v. Zierenberg, Mrs. Zierenberg's evidence was not available against her husband. Lastly, the general feeling was that the Zierenbergs had already been sufficiently punished by the result of the civil action. It is, in our judgment, extremely doubtful whether the prosecution ought to have been undertaken.

\title{
Sir James Stephen.
}

In the excellent biographical notices of the late Sir James Stephen that have appeared in the contemporary press, little, if any, prominence has been assigued to his services in the cause of medico-legal science, and yet not the least brilliant and original part of his splendid record of work was done in this direction. It was he who first suggested, in a paper which was read before the Juridical Society, and which excited at the time in legal circles almost as much commotion as the famous tract in which Dr. Newman "tested the elasticity" of the articles produced at Oxford, a liberal interpretation of the words "nature and quality" in the rules in Macnaghten's case, and this view he subsequently enlarged and defended in his "History of the Criminal Law in England." Nor did Sir James Stephen's judicial practice fall short of his theoretical opinions. He was, unless we are mistaken, the first, as he was certainly the greatest, of the English judges who have endeavoured to manipulate the rules so as to bring them into harmony with scientific knowledge and common sense. Thus, in Reg. v. Davies ("Western Mail," March 15th, 1888, and " Dictionary of Psychological Medicine," Article "Criminal Responsibility," Vol. I., at p. 315) his Lordship said to the jury : "It is said that, according to the law, a man is responsible for his acts when he knows that the act is wrong, and that is true. Now medical men frequently say that many persons who are really mad do know that the act is wrong. But if you will exercise your judgment in the matter you will probably see that, knowing the act is wrong, means nothing more or less than the power of thinking about it, the same as a sane man would think about it; the power of attaining to a full con- 
ception of the horrible guilt there would be in murder, the power of knowing that you are doing that which will destroy life and your soul, and cause sorrow and terror and every kind of frightful consequence, the power of thinking about all this, that power which every sane man possesses. That is the law, as 1 understand it, which by guilt implies the power of discriminating between right and wrong; that is the test of responsibility." In another case (Reg. v. Burt, "Norfolk Chronicle," 10th November, 1885, and " Dictionary of Psychological Medicine," ut sup.), Mr. Justice Stepheu charged the jury: "That if a man were in a state of passionate rage, excited by disease, which violently interfered with his actions, so that he had not a fair capacity to weigh what he was doing or to know that his act was wrong, he was not responsible." It is impossible to doubt that utterances like these, although it is wrong that legal dicta should have to be read in a non-natural sense, ${ }^{*}$ proceeding from the greatest criminal lawyer in his generation, and one, too, who had no sympathy with the idea that crime is only an abnormal or diseased development of virtue, have done much to consolidate and accentuate the judicial departure from the rules in Macnaghten's case in recent years, and to diminish the hostility of the legal towards those members of the medicil profession who insisted that such a departure was necessary.

\section{Lord Hannen.}

What Sir James Stephen did for the law of lunacy on its criminal Lord Hannen did fur it on its civil side. In Waring v. Waring, Lord Brougham, and in Smith v. Tebbits, Lord Penzance, had established as an external standard the principle that the least degree of mental disease was fatal to civil capacity. In the case of Banks v. Goodfellow, Chief Justice Cockburn shook the supremacy of this erroneous doctrine. But in Boughton v. Knight and Durham v. Durham, Lord Hannen destroyed it; and the question of capacity became, as that of criminal responsibility is rapidly tending to become, a question of fact.

- Has not the time arrived for endeavouring to induce the Law Lords to reconsider the subject ? 